\title{
Comparative phylogeny of the Bacillaceae species related to shrimp paste products
}

\author{
Ekachai Chukeatirote* \\ School of Science, Mae Fah Luang University, Chiang Rai 57100, Thailand \\ ${ }^{*}$ Corresponding author, E-mail: ekachai@mfu.ac.th
}

\begin{abstract}
Shrimp paste is one of the traditional seafood products widely consumed in several Asian countries. Although the microbial diversity of shrimp paste remains largely undescribed to date, it has been suggested that the bacterial members of the order Bacillales are predominant. This study was therefore conducted to investigate the bacterial diversity especially for those of the family Bacillaceae, isolated from the shrimp paste products. For this 24 Bacillaceae strains related to the shrimp paste, as well as their nucleotide sequences of the 16S rRNA gene were retrieved from the GenBank database. To elucidate the phylogeny of these Bacillaceae isolates, their 16S rRNA genes were aligned and used to construct the dendogram. Based on the analysis, these 23 Bacillaceae strains were categorized into three major clades: (i) Bacillus subtilis/amyloliquefaciens complex; (ii) Bacillus cereus group; and (iii) non-Bacillus species.
\end{abstract}

Key words: Bacillaceae, Bacillus, fermented seafood, shrimp paste.

\section{Introduction}

Fermented fishery products are widely consumed in many Asian countries, and can be generally classified based on the raw material used (i.e., fish, shrimp, etc.). Shrimp paste is one of these products typically prepared from the planktonous shrimp (Acetes vulgaris) or krill (Mesopodopsis orientalis) (Phithakpol 1993). This product is popular and generally used as a side dish or condiment/ seasoning in several Asian foods. There are a variety of the shrimp paste products which depend on the raw material and the production process; these include Belacan (Brunei and Malaysia), Kapi (Thailand), Ngapi (Myanmar), Saeujot (Korea), and Terasi (Indonesia) (Kim et al. 2014).

Traditional production of shrimp paste consists of four major steps: substrate preparation, salt addition, sun drying, and fermentation. In brief, the shrimp (i.e., Acetes species) is washed thoroughly, shortly sun-dried, and mixed with salt in a ratio by weight of 3 to 1 . The mixture is then pounded and spread on the clean ground under sunlight. Once drained (1 to 2 days), the paste is packed and allowed to ferment under ambient condition for at least 1 month (or longer). When ripening (observed by colour and smell), the product is ready for sale and can be stored for several months (Pongsetkul et al. 2014).

Since traditional production of shrimp paste is processed without sterilisation, it is therefore expected that there would be many microbes involved in the fermentation. In addition, the microbial community may vary considered from the raw material used, the production process and the environmental condition. It is therefore not a surprise that knowledge of microbial diversity of the shrimp paste is scarce. For example, the microflora of Terasi has been previously studied and this reveals a diverse group of bacteria including those in the genera Bacillus, Kurthia, Micrococcus, Pseudomonas, Sporolactobacillus, and Tetragenococcus (Surono, Hosono 1994a,b; Kobayashi et al. 2003).

The pioneering research work of the shrimp paste's microbiota probably comes from Korean Saeujot in which its microbial population was determined using the molecular approach (Han et al. 2014; Lee et al. 2014). This research showed that a diverse group of bacteria is present including those in the phyla Proteobacteria and Firmicutes. However, the Proteobacteria members are found at the beginning and replaced by those of the Firmicutes during the fermentation (Lee et al. 2014). Han et al. (2014) also pointed out that the bacterial members of the order Bacillales are predominant during Saeujot's fermentation. The incidence of this particular bacterial group is expected considering from the selective condition provided for the shrimp paste fermentation.

At least three factors can cause such a selective condition including a protein-rich shrimp substrate, high salt concentration, and anaerobic condition. These shrimp paste products are therefore a target for screening and isolation of some proteolytic and halophilic bacteria (Setyorini et al. 2006; Pakdeeto et al. 2007; Namwong et al. 2009). Considering the potential role of this specific bacterial group, this study was performed to determine their phylogenetic relationship based on the $16 \mathrm{~S}$ rRNA gene. 


\section{Materials and methods}

A total of 23 bacterial isolates in the family Bacillaceae reported to be isolated from shrimp paste were initially retrieved from the GenBank database (Benson et al. 2013). These bacterial samples were obtained under the nucleotide database search using the term 'shrimp paste,' 'Terasi, 'Kapi', etc. Detailed information including their identity, strain code, and accession numbers of the 16S rRNA genes was retrieved (Table 1). For comparative analysis, the bacterial type strains used were Bacillus subtilis DSM10 (AL009126.3), Bacillus licheniformis DSM13 (NC006322.1), Bacillus amyloliquefaciens DSM7 (FN597644), Bacillus mojavensis DSM9205 (AB363735), Bacillus cereus ATCC14579 (BC0007), Lentibacillus kapialis TISTR1551 (AB231905), and Klebsiella pneumoniae DSM30104 (X87276). These sequencing data were analysed using BLAST (Altschul et al. 1990). Sequence alignment and phylogenetic analysis were then carried out using Phylogeny.fr software (Dereeper et al. 2010).

\section{Results and discussion}

Fermented shrimp paste is traditionally produced; without prior sterilisation of raw materials, it is expected that, during the fermentation, this would lead to the growth of various microbes. Unfortunately, information regarding microbial diversity of the shrimp paste products is scarce compared to that of other products (i.e., fermented dairy and soybean products). Recently, Han et al. (2014) described the microbial dynamics and succession during the fermentation of Jeotgal, a Korean fermented shrimp. Using the denaturing gradient gel electrophoresis technique, they found that a diverse group of bacteria was present in which the members of the order Bacillales were predominant (Han et al. 2014).

In this study, an initial search using the terms 'shrimp paste' and other local names of the related products (i.e., Kapi and Terasi) revealed approximately 60 literature sources. These studies included the primer set and the $16 \mathrm{~S}$ rRNA gene sequences of various bacteria isolated from the products. It should be noted that 27 isolates were in the phyla Proteobacteria, consisting of two genera, Methylobacterium and Pseudomonas (data not shown). These strains were isolated from Bulacan, the Philippine shrimp paste. Two strains were lactic acid bacteria (Tetragenococcus halophilus and Tetragenococcus muriaticus) (data not shown). The remaining isolates identified as the members of the family Bacillaceae were then selected for this study and listed in Table 1.

Their 16S rRNA gene sequences were compiled and analysed for their phylogenetic relationship. Based on the evolutionary tree constructed, Fig. 1 showed that there were at least three major clades. Group 1 consisted of five strains

Table 1. List of the Bacillaceae bacteria isolated from the shrimp paste and related products used in this study

\begin{tabular}{|c|c|c|c|c|}
\hline Source & Species & Strain & Accession No. & Remarks \\
\hline Belachan & Bacillus cereus & RE01-BS05 & KJ742939 & Unpublished (Malaysia) \\
\hline \multirow[t]{2}{*}{ Fermented shrimp } & B. mojavensis & F412 & LC020019 & Unpublished (Japan) \\
\hline & Bacillus sp. & AUSH4 & EU878032 & Unpublished (Korea) \\
\hline \multirow[t]{7}{*}{ Kapi } & Bacillus sp. & K-A7 & HQ222303 & Unpublished (Thailand) \\
\hline & Bacillus sp. & C5 & JQ814721 & Unpublished (Thailand) \\
\hline & Bacillus sp. & KPa7 & JQ814720 & Unpublished (Thailand) \\
\hline & Lentibacillus & PN7-6 & NR041319 & Pakdeeto et al. 2007 \\
\hline & Oceanobacillus & SSK2-2 & NR112740 & Namwong et al. 2009 \\
\hline & Virgibacillus & KN3-8-4 & LC041942 & Unpublished (Thailand) \\
\hline & Virgibacillus & TKNR13-3 & HМ364289 & Unpublished (Thailand) \\
\hline \multirow[t]{3}{*}{ Ngapi } & B. subtilis & NP1-1 & AB168129 & Aung et al. 2004 \\
\hline & Bacillus sp. & NP3-2 & AB168130 & Aung et al. 2004 \\
\hline & B. licheniformis & 1LB5 & JQ266341 & Unpublished (India) \\
\hline \multirow[t]{3}{*}{ Terasi } & Bacillus sp. & S2-3 & FJ217159 & Unpublished (Thailand) \\
\hline & Bacillus sp. & S4-5 & FJ217160 & Unpublished (Thailand) \\
\hline & Bacillus sp. & S1-13 & JX441363 & Unpublished (Thailand) \\
\hline \multirow[t]{4}{*}{ Saeujot } & Alkalibacillus & BH163 & AY671976 & Jeon et al. 2005 \\
\hline & B. cereus & SCH-1 & KC878876 & Han et al. 2014 \\
\hline & Paenibacillus & SCH-2 & KC878877 & Han et al. 2014 \\
\hline & Virgibacillus & YIM-kkny16 & AY121439 & Unpublished (China) \\
\hline \multirow[t]{2}{*}{ Shrimp paste } & Allobacillus & B3A & NR116607 & Sheu et al. 2011 \\
\hline & Bacillus & NSPM & FJ347756 & Unpublished (Taiwan) \\
\hline Shrimp sauce & B. subtilis & SK11004 & FJ437210 & Unpublished (China) \\
\hline
\end{tabular}




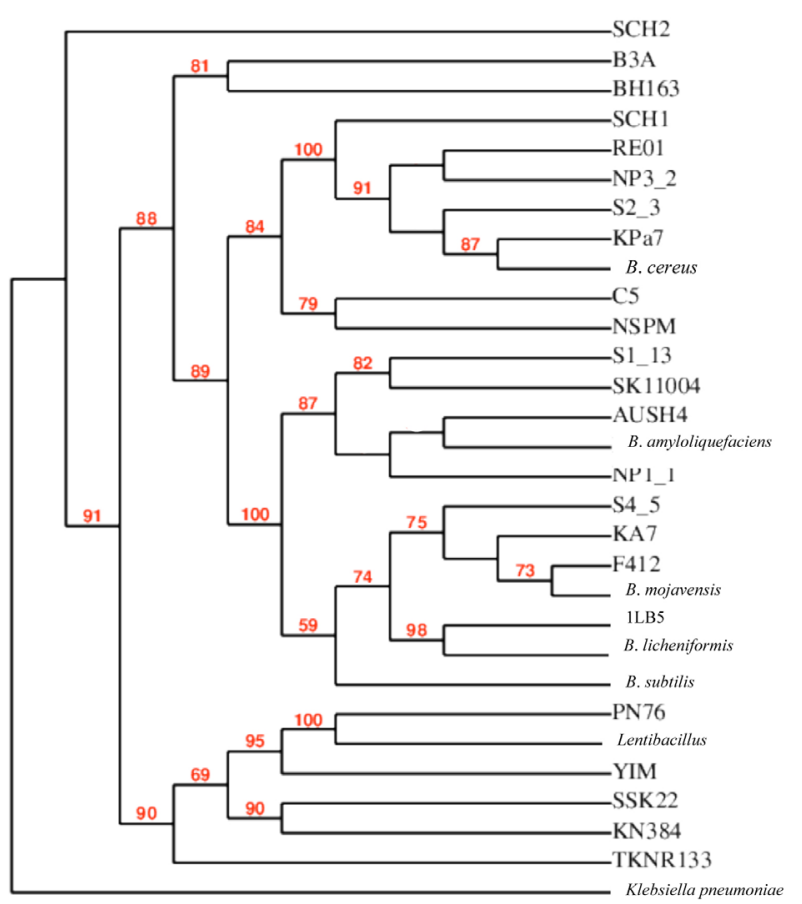

Fig. 1. Cladistic tree constructed with the $16 \mathrm{~S}$ rRNA gene sequences of the Bacillaceae bacteria isolated from the shrimp paste products. Bootstrap confidence levels greater than $50 \%$ are presented at the nodes.

(SCH1, RE01, NP3-2, S2-3, and KPa7) which were clustered with a $B$. cereus type strain. There were two strains ( $\mathrm{C} 5$ and NSPM) that formed a distinct clade related to Group 1 and initially designated as Bacillus spp. from the unpublished work of Thailand and Taiwan, respectively. Group 2 was comprised of eight strains (S1-13, SK11004, AUSH4, NP1-1, S4-5, KA7, F412, and 1LB5) including the type strains of B. subtilis, B. amyloliquefaciens, B. licheniformis, and $B$. mojavensis. The eight remaining isolates $(\mathrm{SCH} 2$, B3A, BH163, PN7-6, YIM-kkny16, SSK2-2, KN3-8-4, and TKNR13-3) were classified in Group 3 and represented the non-Bacillus species.

In addition, as shown in Table 1 , there were nine bacterial isolates in which their identity remained unknown, including the strains AUSH4, K-A7, C5, KPa7, NP3-2, S2-3, S4-5, S1-13, and NSPM (thus designated as Bacillus spp.). These bacterial isolates were then identified based on relatedness of the $16 \mathrm{~S}$ rRNA gene sequence, as shown in Table 2. In general, the species identification was in agreement with the data obtained from the phylogenetic tree. For example, the unidentified strains of S2-3, NP3-2, and Kpa7 were identified as B. cereus (Fig. 1 and Table 2). The strain NSPM was re-identified as B. cohnii distantly related to the B. subtilis group.

The phylogenetic relationship of the Bacillaceae strains isolated from the shrimp paste products was determined in the present study. It should be noted, however that the sole use of the 16S rRNA gene sequence proved to be difficult for Bacillus species identification (especially for
Table 2. Species identification of the unidentified or wrongly identified Bacillaceae bacteria isolated from the shrimp paste products. Nucleotide sequence similarities were presented in the parentheses

\begin{tabular}{ll} 
Strain & Species identification \\
AUSH4 & B. atrophaeus $(86.38)$ \\
\hline K-A7 & B. subtilis $(99.54)$ \\
C5 & B. infantis $(99.42)$ \\
KPa7 & B. cereus $(99.79)$ \\
NP3-2 & B. cereus $(99.46)$ \\
S2-3 & B. cereus $(99.86)$ \\
S4-5 & B. subtilis $(99.56)$ \\
S1-13 & B. subtilis $(99.68)$ \\
NSPM & B. cohnii $(96.34)$ \\
\hline
\end{tabular}

B. subtilis species). There are some Bacillus species that are closely related to B. subtilis, and they are often referred to as the 'subtilis-group' or ' $B$. subtilis species complex' which includes B. amyloliquefaciens, B. atrophaeus, and B. mojavensis (Rooney et al. 2009). Additional information on such strains regarding phenotypic characteristics (i.e., morphology and biochemical profiles) as well as other biomarkers (i.e., sequencing data of the gyrase and RNA polymerase genes) is important for further analysis. Once available, these data can be expected to provide insight on the antiquity and diversity of this widely consumed food.

\section{Conclusions}

Information on the shrimp paste microbiota is presently scarce. This paper highlights the bacterial diversity especially for those of the family Bacillaceae. Considered that shrimp paste products are widely distributed in several Asian countries, the Bacillaceae members appear to be predominant. This is the first report to describe the phylogeny of the Bacillaceae bacteria isolated from shrimp paste products.

\section{References}

Altschul S.F., Gish W., Miller W., Myers E.W., Lipman D.J. 1990. Basic local alignment search tool. J. Mol. Biol. 215: 403-410.

Aung W., Naylin N., Zheng Z., Watanabe Y., Hashinaga F. 2004. Antioxidant and antibacterial activities of bacteria from $\mathrm{Ngapi}$, a Burmese salted and fermented shrimp paste. Biocontrol Sci. 9: 117-122.

Benson D.A., Cavanaugh M., Clark K., Karsch-Mizrachi I., Lipman D.J., Ostell J., Sayers E.W. 2013. GenBank. Nucl. Acids Res. 41: D36-D42.

Dereeper A., Audic S., Claverie J.M., Blanc G. 2010. BLASTEXPLORER helps you building datasets for phylogenetic analysis. BMC Evol. Biol. 10: 8.

Han K.I., Kim Y.H., Hwang S.G., Jung E.G., Patnaik B.B., Han Y.S., Nam K.W., Kim W.J., Han M.D. 2014. Bacterial community dynamics of salted and fermented shrimp based on denaturing gradient gel electrophoresis. J. Food Sci. 79: M2516-M2522.

Jeon C.O., Lim J.M., Lee J.M., Xu L.H., Jiang C.L., Kim C.J. 2005. 
Reclassification of Bacillus haloalkaliphilus Fritze 1996 as Alkalibacillus haloalkaliphilus gen. nov., comb. nov. and the description of Alkalibacillus salilacus sp. nov., a novel halophilic bacterium isolated from a salt lake in China. Int. J. Syst. Evol. Microbiol. 55: 1891-1896.

Kim Y.B., Choi Y.S., Ku S.K., Jang D.J., Ibrahim H.H., Moon K.B. 2014. Comparison of quality characteristics between belacan from Brunei Darussalam and Korean shrimp paste. J. Ethn. Foods 1: 19-23.

Kobayashi T., Kajiwara M., Wahyuni M., Kitakado T., Hamada-Sato N., Imada C., Watanabe E. 2003. Isolation and characterisation of halophilic lactic acid bacteria isolated from "terasi" shrimp paste: A traditional fermented seafood product in Indonesia. J. Gen. Appl. Microbiol. 49: 279-286.

Lee S.H., Jung J.Y., Jeon C.O. 2014. Effects of temperature on microbial succession and metabolite change during saeu-jeot fermentation. Food Microbiol. 38: 16-25.

Namwong S., Tanasupawat S., Lee K.C., Lee J.S. 2009. Oceanobacillus kapialis sp. nov., from fermented shrimp paste in Thailand. Int. J. Syst. Evol. Microbiol. 59: 2254-2259.

Pakdeeto A., Tanasupawat S., Thawai C., Moonmangmee S., Kudo T., Itoh T. 2007. Lentibacillus kapialis sp. nov., from fermented shrimp paste in Thailand. Int. J. Syst. Evol. Microbiol. 57: 364369.
Phithakpol B. 1993. Fish fermentation in Thailand. In: Lee C.H., Steinkraus K.H., Reilly P.J. (eds) Fish Fermentation Technology. United Nations University Press, Tokyo, pp. 155-168.

Pongsetkul J., Benjakul S., Sampavapol P., Osako K., Faithong N. 2014. Chemical composition and physical properties of salted shrimp paste (Kapi) produced in Thailand. Int. Aqua. Res. 6: $155-166$.

Rooney A.P., Price N.P.C., Ehrhardt J.L., Swezey J.L., Bannan J.D. 2009. Phylogeny and molecular taxonomy of the Bacillus subtilis species complex and description of Bacillus subtilis subsp. inaquosorum subsp. nov. Int. J. Syst. Evol. Microbiol. 59: 2429-2436.

Setyorini E., Takenaka S., Murakami S., Aoki K. 2006. Purification and characterisation of two novel halotolerant extracellular proteases from Bacillus subtilis strain FP-133. Biosci. Biotechnol. Biochem. 70: 433-440.

Sheu S.Y., Arun A.B., Jiang S.R., Young C.C., Chen W.M. 2011. Allobacillus halotolerans gen. nov., sp. nov. isolated from shrimp paste. Int. J. Syst. Evol. Microbiol. 61: 1023-1027.

Surono I.S., Hosono A. 1994a. Chemical and aerobic bacterial composition of "Terasi", a traditional fermented product from Indonesia. J. Food Hyg. Soc. Japan 35: 299-304.

Surono I.S., Hosono A. 1994b. Microflora and their enzyme profile in “Terasi” starter. Biosci. Biotechnol. Biochem. 58: 1167-1169. 